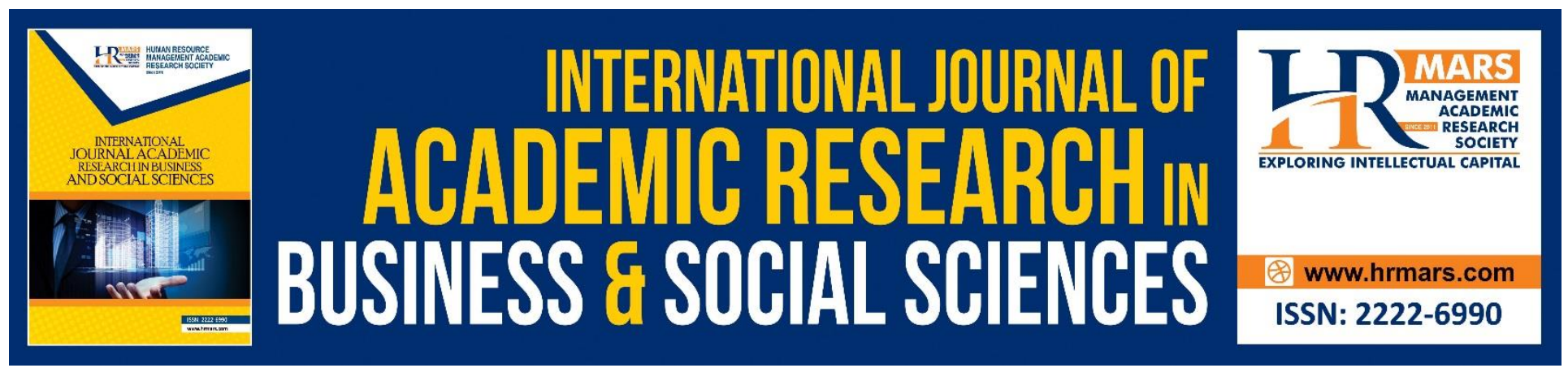

\title{
Library Therapeutic Landscape Quality Approaches in Public Libraries: A Pilot Study
}

Haslinda Husaini, Siti Arpah Noordin, Shamila Mohamed Shuhidan, Farrah Diana Saiful Bahry

To Link this Article: http://dx.doi.org/10.6007/IJARBSS/v8-i9/4603

DOI: $\quad 10.6007 /$ IJARBSS/v8-i9/4603

Received: 21 August 2018, Revised: 19 September 2018, Accepted: 29 Sept 2018

Published Online: 15 October 2018

In-Text Citation: (Husaini, Noordin, Shuhidan, \& Bahry, 2018)

To Cite this Article: Husaini, H., Noordin, S. A., Shuhidan, S. M., \& Bahry, F. D. S. (2018). Library Therapeutic Landscape Quality Approaches in Public Libraries: A Pilot Study. International Journal of Academic Research in Business and Social Sciences, 8(9), 439-451.

Copyright: (c) 2018 The Author(s)

Published by Human Resource Management Academic Research Society (www.hrmars.com)

This article is published under the Creative Commons Attribution (CC BY 4.0) license. Anyone may reproduce, distribute, translate and create derivative works of this article (for both commercial and non-commercial purposes), subject to full attribution to the original publication and authors. The full terms of this license may be seen at: http://creativecommons.org/licences/by/4.0/legalcode

Vol. 8, No. 9, September 2018, Pg. 439 - 451

Full Terms \& Conditions of access and use can be found at http://hrmars.com/index.php/pages/detail/publication-ethics 


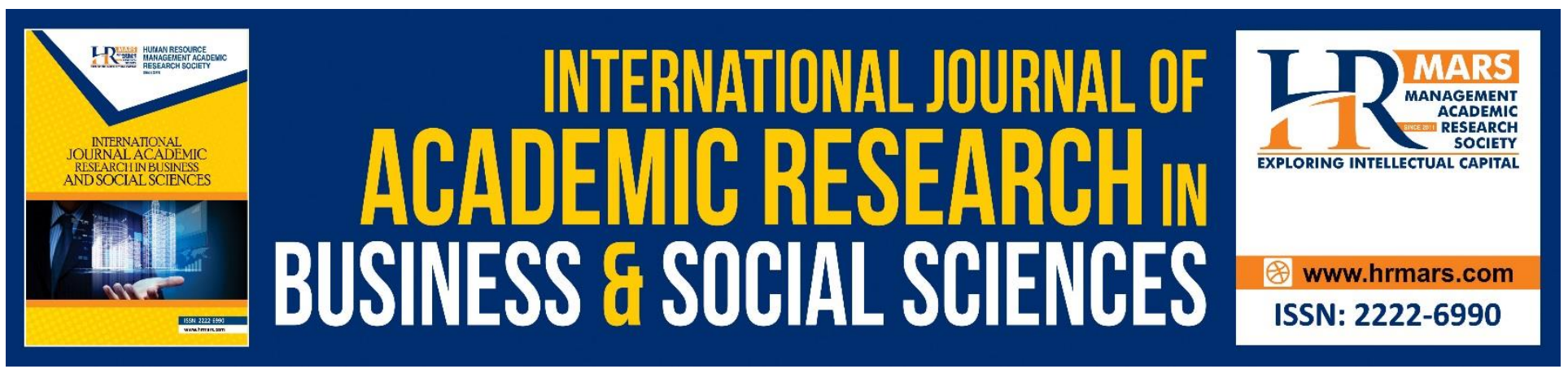

\title{
Library Therapeutic Landscape Quality Approaches in Public Libraries: A Pilot Study
}

\author{
Haslinda Husaini \\ Faculty of Information Management, MARA University of Technology, Shah Alam, Malaysia \\ Email: haslinda3145@salam.uitm.edu.my
}

Siti Arpah Noordin

Faculty of Information Management, MARA University of Technology, Shah Alam, Malaysia

Email: siti@salam.uitm.edu.my

\section{Shamila Mohamed Shuhidan}

Faculty of Information Management, MARA University of Technology, Shah Alam, Malaysia

Email: shamila@salam.uitm.edu.my

\author{
Farrah Diana Saiful Bahry \\ Faculty of Information Management, MARA University of Technology, Shah Alam, Malaysia \\ Email: farrahdiana@salam.uitm.edu.my
}

\begin{abstract}
Consideration of user satisfaction should be the main business in the public libraries business. It serves as evaluating benchmarks on the library performance. Satisfaction is depends, it could be the overall library as a service provider including on user expectation of place, services and facilities. The purpose of this study is to identify the elements of a public library therapeutic landscape quality for measuring the level of library therapeutic satisfaction available in the library of past and present. With a focus on the public library, this study examines user perception of the quality of their therapeutic landscape provided. Using a developed therapeutic landscape quality questionnaire, 30 users were randomly selected to answer. It was analyzed with therapeutic landscape dimension (natural/built environment, social environment and spiritual environment). A 108- item, 5 domain questionnaire excluding the respondent information on the view of library user regarding the library therapeutic landscape quality and satisfaction was developed based on a literature, theories and empirical study. This paper aims to describe the process involved and outcomes in undertaking a pilot study as a preparation for the real data collection which is to study library therapeutic landscape quality and satisfaction among the well established and modern public libraries in Malaysia. Data
\end{abstract}


INTERNATIONAL JOURNAL OF ACADEMIC RESEARCH IN BUSINESS AND SOCIAL SCIENCES

Vol. 8, No. 9, Sept. 2018, E-ISSN: 2222-6990 @ 2018 HRMARS

analyses were conducted with the use of statistical software. Output from the analysis, shows that the instruments are reliable and there is no abnormality on the data.

Keywords: Public library, therapeutic landscape, quality, users' expectation, users' perception, satisfaction,

\section{Introduction}

In a highly competitive economic and social environment, generally life has become more demanding as well as challenging. The rapid pace of development in terms of social and economic development in Malaysia is tremendous. This can be seen with rising living standards. But no doubt also, the side effects result from rapid social development, economy and technology. The crime rate in society is increasing. Statistics also show involvement in the crime index increasing from year to year. Transmission to psychology and mental problems also seem increasingly prevalent.

Those rapid economic and social changes eventually lead to many psychological problems in Malaysia. This is due to the modern culture and negative influences which leads to various forms of social ills (Krauss, 2008; The Online Star, 2004). Feeling depressed with increasing lifestyle crave to various needs and requirements to be met even cause people today are exposed to stress and depress symptoms.

Normally when an individual or people, when you are in a stressful situation, especially pressure at work, people will often choose to escape for a moment with a vacation to places that can bring peace of the surrounding atmosphere. Some of them went to visit tourist areas on the coast, the mountains, cool and green area or take advantage of the holiday and indulge in luxury hotels or went to the pilgrimage area where they can found some peace.

Surprisingly, those environments are able to ease people pressure and change people's mood from various perspectives. This have been proved by the research evidences that explained how and why natural and landscape sceneries helped people. The ideas of this theory come from the therapeutic landscape by Gesler (1992). According to Husaini, Noordin, Shuhidan $(2015,2016)$, the social environment and the spiritual environment influence their library therapeutic satisfaction towards the feeling of well being or stress reduction and it is being supported by the study by Suhar (2012) The success of it will be achieved by the user's satisfaction on how they benefit the physical interior environments.

What is about the relation of therapeutic landscape with the public library? Today, public libraries are contrary to traditional public library as the primary of information. Many research on public libraries have been highlighting the role of public library to support the information, educational, cultural and recreational needs of communities with quality library services to fulfill the needs of living (ladhari \& Morales, 2007; Brewster, 2014). More important is public libraries have a special engagement or actively engaged with development of social well being of the society (Lippman et.al., 2011) allocates resources to reducing crime and to improve citizenship especially in the new era where the development and the changes in the society lead to many psychological problems in 
INTERNATIONAL JOURNAL OF ACADEMIC RESEARCH IN BUSINESS AND SOCIAL SCIENCES Vol. 8, No. 9, Sept. 2018, E-ISSN: 2222-6990 @ 2018 HRMARS

Malaysia due to the modern global culture and negative influences which can eventually lead to various forms of social ills (Krause, 2008; The Star Online, 2014).

Stemming from the issues that threaten the well-being of society, which cause daily stresses of modern society, the study aims at identifying the elements of a public library therapeutic landscape quality for measuring the level of library therapeutic satisfaction available in the library of past and present. With a focus on the public library, this study examines user perception of the quality of their therapeutic landscape provided. Intentionally, the study also works on the gap that is available and further tests the relationship of both concepts in the public libraries context. Besides, the study argues that becoming library therapeutic landscape is not mainly focuses on the books and resources, but it should focus on the other aspect or criteria which are core to the therapeutic landscape.

In today's chaotic life, people need a place where they can escape from the chaos. It's kind of relief when be surrounded by the peaceful ambience, environments that be able to encourage people to react positively even though they are facing a problem. In a highly competitive economic and social environment, society are becoming more demanding in their choice of life, Hence, it is require the qualities that be able to make public library an essential element of community life. Public libraries need to define their existence in the community. By highlighting the role of public libraries will be more dominant, visible and significant in the society. It is easier when the library understands the needs of library users in term of library therapeutic landscape. The satisfaction is necessary for better management and development of the society.

It hypothetically assumes that the library environment is highly possible when library therapeutic landscape is strategically used by the library to develop. Having a solid and an accurate data is an advantage as it helps the library to have a good decision and good management (Brewster, 2014). To achieve this, library need to understand what library user expectation and perception in terms of library therapeutic landscape quality and satisfaction. It is important to ensure therapeutic landscape used by the library gives an impact towards the society.

Due to that, a pilot study was carried out with the aims to attest the validity and reliability of the measurement used in the study. To get a good study design, pilot study was proposed. It is a crucial element in the research as it can provide valuable insights on the actual study.

Furthermore, literatures and previous research in varieties of areas show the important of it from the aspects of developing, testing, assessing, determining, identifying, collecting the research question, research plan, resources, data collection, target audience, implication and significant. The advantages of conducting a pilot study is that it may give advance warning about where the main research project could fail, where research protocols may not be followed, or whether proposed methods or instruments are inappropriate, too expensive or too complicated (Van Teijlingen and Hundley, (2001, 2002) and (Van Teijlingen, Rennie, Hundley and Graham, 2001). Gardner, Gardner, MacLellan and Osbornea (2003) have claimed that a pilot study report contains information on practices and problems experienced by researchers.

To that, this paper intended to present the result of the pilot test. It is related with library therapeutic landscape quality which is measured in terms of expected and perceived of library natural/built 
INTERNATIONAL JOURNAL OF ACADEMIC RESEARCH IN BUSINESS AND SOCIAL SCIENCES

Vol. 8, No. 9, Sept. 2018, E-ISSN: 2222-6990 @ 2018 HRMARS

environment, library social environment and library spiritual environment and its relationships with library therapeutic satisfaction.

\section{Literature Review}

Interest in service quality in organizations has been on the increase globally and no doubt that it is receiving a lot of attention from many parties including public libraries, which also plays an important role in the formation of society. Further more, role of public libraries today is contrary to traditional public libraries as the primary of information. Globally known that service quality (ServQUAL) theory by Parasuraman, Zeithaml, and Berry (1988) has been introduced and used in many institution and organization, so do with library quality (LibQUAL) by the Association of Research Libraries (Association of Research Libraries Statistics and Assessment Program, 2014). This theory has been implemented due to the needs to improve the service at a better level of acceptance and satisfaction of user. The concept is to provide better quality services to satisfy the customer, it is the method of evaluation for quality.

The rapid changes of technology and the increasing competition required library to improve the quality not only in services to satisfy the customer but also on their library therapeutic satisfaction. With the global changes, quality of life playing an important roles so that in this study, the library user be able to feel the happiness, life satisfaction and the needs satisfaction approaches through the library's role as an environment but not as service provider (Husaini, Noordin, and Shuhidan, 2015; Noordin, Husaini, and Shuhidan, 2016)

The idea of therapeutic landscape has been widely used to describe the relationship between place and improvements in mental health (Brewster, 2014). Therapeutic landscapes itself is taking a role as a platform of recovery process whereby its concept which includes safe spaces, favorite places and enabling places; have been outlined to suggest that the attributes support recovery and encourage well being (Duff, 2012; Yates et. al., 2012).

Wilbert Gesler (1992) developed the concept of therapeutic landscapes in a health geographical thinking. Its theoretical origins lie in cultural ecology, structuralism and humanism. The analytical framework of natural, built, social and spiritual environments contribute to healing and well being in places - broadly termed landscapes (Gesler, 2003). The theory is mainly applied to places that have achieved a reputation for healing (Gesler, 2003) or extended to places that promote and maintain well being and health (Williams, 1999, 2000).

In fact, other research evidences have explained how and why natural views and landscape sceneries ease people's pressure and change their mood from various perspectives, including: medical geography (Gesler, 2003), environmental psychology (Kaplan and Kaplan, 1989; Kaplan, 1992; Ulrich, 1984, 1999), ecological psychology (Vries, 2010); Moore and Cosco, 2010), and horticultural therapy (Detweiler, et.al., 2012; Soderback et al., 2004).

The model of therapeutic landscapes by Gesler (1998) that consists of 3 dimensions which are natural and built environment, social environment and spiritual environment and supported by empirical studies done by William, 1998; Palka, 1999; Thurber \& Malinowski, 1999; Kearns \& Barnet, 1999; Scarpaci, 1999; Kearns \& Collins, 2000; Williams, 2002, Wilson, 2003; Miligian et.al., 2004; Martin 
INTERNATIONAL JOURNAL OF ACADEMIC RESEARCH IN BUSINESS AND SOCIAL SCIENCES

Vol. 8, No. 9, Sept. 2018, E-ISSN: 2222-6990 @ 2018 HRMARS

et.al., 2005; Korpela and Ylean, 2007; Ravi, 2008; Brewster, 2014; Montealleh, 2015. Those studies had extended the theory in other research field.

Some research look on the integrating landscape with library spaces (Montealleh, Parsaee, Sheybani, 2015) that integrate library space and landscape affordance to boost potentials to increase learning among the library users as they pay attention to the landscape capability in designing library.

There are also therapeutic elements being practiced in the library daily without realizing the ability to help library to be a suitable place to demonstrate therapeutic landscape, especially when library is one of the organizations that has a close engagement with society (Lippman et al., 2011). Some studies look at library as a place which only contains services, facilities and collection (Ludwig and Starr, 2005) and recently the studies have started to evaluate the therapeutic landscape from the aspect of places of opportunity, place of restoration, place of sociability and place of safety by Sampson (2010).

The current studies by Brewster (2014) discusses the public library as therapeutic landscape, it's a qualitative case study. They are focused on one particular group of public library service users with mental health problems. The participants come from three different groups which a bibliotherapy group, a poster on a public library notice that asking for volunteers to be interviewed about their use of books for well-being and those who volunteers based from their reading articles about the project for a local mental health. The aim is to look on how library can contribute to their feel of well being. This study is based on Gesler (1992) theory in therapeutic landscape. The participants were interviewed about their experience with library from a few aspects such as; building, type of space, library atmosphere, modern purpose-built libraries, facilities, geographical area, library appealing, library ambience and many more which are related to library's environment. Those participants referred to their library use as therapeutic, exploring the influence of the library that had a positive impact on mental health. This study proved that the public library may help with the everyday recovery work of mental health. Those uniqueness and its qualities is subjectively therapeutic for some people.

Those previous studies discussed earlier have led this current study to be initiated. However, while this study does not aim to measure the well being of library users, it is focused on measuring the public library therapeutic landscape quality and satisfaction. Since the nature of the business of libraries is service oriented, the quality of the service from the aspect of therapeutic landscape needs to be measured to ensure satisfaction of the library therapeutic landscape elements. As found and agreed in various literature from the recent past, public libraries must improve the quality not only in service but also on therapeutic landscape in order to survive and success in service performance ( Husaini H., Noordin, S.A and Shuhidan S.M., 2015; Noordin, S.A, Husaini H and Shuhidan S.M., 2016)

\section{Methodology}

This project began with the intention to inspire satisfaction using library therapeutic landscape quality as a motivator towards well being. Upon researching the topic, it became apparent that there was a serious lack of data supporting how library therapeutic landscape quality could be used as a motivator for sustainable satisfaction. In response, the methods for this project took a four-tiered approach in an attempt to fill this gap: survey construction based on existing literature, exploratory 
INTERNATIONAL JOURNAL OF ACADEMIC RESEARCH IN BUSINESS AND SOCIAL SCIENCES

Vol. 8, No. 9, Sept. 2018, E-ISSN: 2222-6990 (c) 2018 HRMARS

study, survey and pilot testing, and running reliability and validity tests on the data to ensure the usefulness of the results.

\section{Survey}

An extensive literature review was conducted on the relationship between therapeutic landscape quality and library services and facilities. It was during this phase that it became apparent that a new assessment tool would have to be created as a tool to comprehensively assess various categories of quality which sustainability categories did not exist at this time. Through the literature review several categories emerged and questions associated with each category were compiled. Three categories for therapeutic landscape quality were decided upon due to the original theory of therapeutic landscape.

Four questions were originally generated for each item along with how they would be scored based on previous assessments and emerging questions from the literature. At the beginning, the pretesting was carried out using the instrument developed to identify any problems related to the questions, format, style, terms, fonts and etc. The instrument was then submitted to the experts for their review of content validity. Upon further consideration it was deemed necessary to have more questions which would either provide additional information or act as a test for one of the existing questions by rewording it. The process of removing questions is easier if the pilot test proved the questions to be unhelpful rather than having to add new questions and repeat the testing.

Because the assessment tool is an entirely new creation, it was important to build ways to test for different forms of validity and reliability. By including questions in each category that were very similar, only slightly reworded or inverted to the negative form, it would help test for consistency, or reliability, of participant responses. The questions were designed to assess expectation and perception. The diversity of questions was intended to help increase the content validity of the survey. Questions were sorted based on response type: word response, pick one answer, or fivepoint Likert scales, and data were analyzed using descriptive statistical techniques. The questions were then arranged into "my expectation" and "my perception" which both contain all the questions, simply in different orders and categories.

\section{Pilot Testing}

Once the survey was complete, testing was scheduled. This was the first testing of this tool and was designed to be completed in person rather than online to reduce outside distraction. It was decided that library users at Selangor state library would act as the population for this initial testing because they are relatively easy to recruit and they act as a homogenous group of people with many similarities in demographic terms but would still be comprised of unique individuals. This would be very effective for determining the reliability and validity of the assessment tool.

This pilot study was undertaken over a 3-month period using the methodology of the main study. Within the time period included initial preparation of printed materials, research assistant education and questionnaire distribution to the target audience and the run of pre-testing to the sample of participants such as; professor, associate professors, doctoral studies, librarians, language professional, subject matter experts and some random participants from library user. 
INTERNATIONAL JOURNAL OF ACADEMIC RESEARCH IN BUSINESS AND SOCIAL SCIENCES Vol. 8, No. 9, Sept. 2018, E-ISSN: 2222-6990 @ 2018 HRMARS

The feedback was considered and necessary amendments were made based on the comments and feedback. A sample size of $10 \%$ of the main study sample was to be used. The aim of the study was to test the instruments reliability and validity and to identify if there is any hiccup in the instruments that can cause a weakness. The intended objective for the pilot study was to ensure the validity and reliability of the research instrument. In detail, the purposes of the pilot study were as follows :

1. To identify if there are any related problems to the questions

2. To get the preliminary feedback from the respondents on the format, terms used, length, fonts used, sentence structure, the instructions method of the developed instrument.

3. To evaluate the suitability of the use instruments

4. To examine the appropriateness of the instruments

5. To access some of the like hood of data reliability

6. To access the difficulties in answering the instruments

7. To ensure the data collected able to answer the study question

8. To confirm the sample size for the main study

9. To estimate the process, steps and procedures

The pilot study was conducted over a period of 3 months. The research population comprises of all library users of selected public libraries. Sample size for this pilot project was 30 library users, which represented $10 \%$ of the sample size calculated for the main study.

A 108-item, five-domain section in the questionnaire was developed based on a literature review and an exploratory study. Participants had up to one hour to complete the survey if they needed the time. However, most participants completed the testing in 15 to 20 minutes. 50 copies of questionnaire were distributed and 50 were returned. Participants were given the opportunity to withdraw from the study at any time along with instructions as to how their data could be removed from the study. Participants were also told that they did not have to answer any questions that made them feel uncomfortable. Participants created a participant code so their answers would remain anonymous but the answers could be compared from one session to the other. Hence, only 30 returned questionnaires were considered for analysis. The data were analyzed using SPSS version 19. To test the reliability by measuring the internal consistency of the instrument, Cronbach's alpha was used.

\section{Result of Reliability Test}

In statistic (classical test theory), Cronbach's alpha is a measure used to assess the reliability, or internal consistency, of a set of scale or test items. In other words, the reliability of any given measurement refers to the extent to which it is a consistent measure of a concept, and Cronbach's alpha is one way of measuring the strength of that consistency. The resulting $\alpha$ coefficient of reliability ranges from 0 to 1 in providing this overall assessment of a measure's reliability. If all of the scale items are entirely independent from one another (i.e., are not correlated or share no covariance), then $\alpha=0$; and, if all of the items have high covariances, then $\alpha$ will approach 1 as the number of items in the scale approaches infinity.

In other words, the higher the $\alpha$ coefficient, the more the items have shared covariance and probably measure the same underlying concept. Although the standards for what makes a "good" $\alpha$ coefficient are entirely arbitrary and depend on the theoretical knowledge of the scale in question, many 
INTERNATIONAL JOURNAL OF ACADEMIC RESEARCH IN BUSINESS AND SOCIAL SCIENCES Vol. 8, No. 9, Sept. 2018, E-ISSN: 2222-6990 @ 2018 HRMARS

methodologists recommend a minimum $\alpha$ coefficient between 0.65 and 0.8 (or higher in many cases); $\alpha$ coefficients that are less than 0.5 are usually unacceptable, especially for scales purporting to be unidimensional.

Table 1. Reliability Analysis Cronbach's Alpha (Pilot Study)

\begin{tabular}{|c|c|c|c|c|}
\hline \multirow{2}{*}{$\begin{array}{l}\text { Independent } \\
\text { Variables }\end{array}$} & \multirow{2}{*}{ Dimensions } & \multirow{2}{*}{$\begin{array}{l}\text { No. of } \\
\text { items }\end{array}$} & \multicolumn{2}{|c|}{ Cronbach's Alpha } \\
\hline & & & Expected & Perceived \\
\hline \multirow{4}{*}{$\begin{array}{l}\text { Library } \\
\text { Natural/built } \\
\text { Environment }\end{array}$} & $\begin{array}{l}\text { Physical: Artificial Element } \\
\text { (body, flooring, furniture) }\end{array}$ & 4 & 0.876 & 0.846 \\
\hline & $\begin{array}{l}\text { Physical: Natural ones (water, } \\
\text { vegetation, topography) }\end{array}$ & 4 & 0.780 & 0.616 \\
\hline & $\begin{array}{l}\text { Non-Physical: Climatic factors } \\
\text { (temperature, radiation, } \\
\text { humidity) }\end{array}$ & 4 & 0.874 & 0.767 \\
\hline & $\begin{array}{l}\text { Non-Physical: Non-climatic } \\
\text { factors (light, ventilation, } \\
\text { smells, noise) }\end{array}$ & 4 & 0.931 & 0.770 \\
\hline \multirow{5}{*}{$\begin{array}{l}\text { Library Social } \\
\text { Environment }\end{array}$} & Library Social Inclusion & 4 & 0.858 & 0.776 \\
\hline & Library Personnel & 4 & 0.796 & 0.689 \\
\hline & Library Services \& Facilities & 4 & 0.777 & 0.771 \\
\hline & Library Programs & 4 & 0.882 & 0.857 \\
\hline & Library Collection & 4 & 0.710 & 0.802 \\
\hline \multirow{4}{*}{$\begin{array}{l}\text { Library } \\
\text { Spiritual } \\
\text { Environment }\end{array}$} & Symbolism & 4 & 0.898 & 0.818 \\
\hline & Supernatural Healing Power & 4 & 0.877 & 0.818 \\
\hline & Belief & 4 & 0.895 & 0.876 \\
\hline & Feeling of Well Being & 4 & 0.915 & 0.806 \\
\hline $\begin{array}{l}\text { Dependent } \\
\text { Variable }\end{array}$ & & $\begin{array}{l}\text { No. of } \\
\text { items }\end{array}$ & \multicolumn{2}{|c|}{ Cronbach's Alpha } \\
\hline $\begin{array}{l}\text { Library } \\
\text { Therapeutic } \\
\text { Satisfaction }\end{array}$ & & 3 & \multicolumn{2}{|c|}{0.686} \\
\hline
\end{tabular}

Table 1 displays the results of the reliability analysis based on the responses of 30 library users who participated in the survey. All factors were found to be good reliability with the Cronbach's alpha results above 0.6 . The above results have shown the acceptable value of the reliability standard. It also indicates that the selected items truly represent the hypothesized constructs in the research framework.

According to Hair et al., (2010) content reliability is used to determine if the hypothesized items are actually measuring their constructs. In theory, a Cronbach's alpha of a loading 0.7 has been suggested by Nunnally and Bernstein (1994) as the cut off criterion, while the highest score stood at 0.91. George and Mallery (2003) provide the following rules of thumb related to Cronbach's alpha scores: 
INTERNATIONAL JOURNAL OF ACADEMIC RESEARCH IN BUSINESS AND SOCIAL SCIENCES Vol. 8, No. 9, Sept. 2018, E-ISSN: 2222-6990 @ 2018 HRMARS

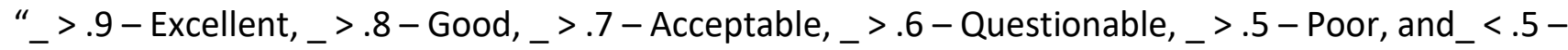
Unacceptable.

The summary of SPSS output in the table above presents the overall consistency. Cronbach's alpha among the items of all constructs within the instruments was in the ranged from 0.616 to 0.931 , indicating that the overall index of the internal consistency of the scale in the instrument is reliable and acceptable. There is no abnormality on the data. Each item was evaluated individually to ensure item reliability. However, 0.6 is allowed as a minimum level when a newly developed item is included (Hair et al., 1998; Nunnally, 1978).

\section{Discussion \& Conclusion}

The dependent variable is the library therapeutic satisfaction, measured in terms of library user satisfaction. The independent variables are based on the therapeutic landscape theory by Gesler (1992), service quality (ServQUAL) theory by Parasuraman, Zeithaml, and Berry (1988) and library quality ( LibQUAL) by the Association of Research Libraries (Association of Research Libraries Statistics and Assessment Program, 2014). From these three aspects which are therapeutic landscape, ServQUAL and LibQUAL, the researcher extends the study into library therapeutic landscape quality to increase library user therapeutic satisfaction. With these elements, role of the public libraries will be more visible and significant to the society development.

As the independent variable is based on the theory of therapeutic landscape, it consists of three dimensions, namely, library natural/built environment, library social environment and library spiritual environment. Figure 1 below illustrates the conceptual model for this study.

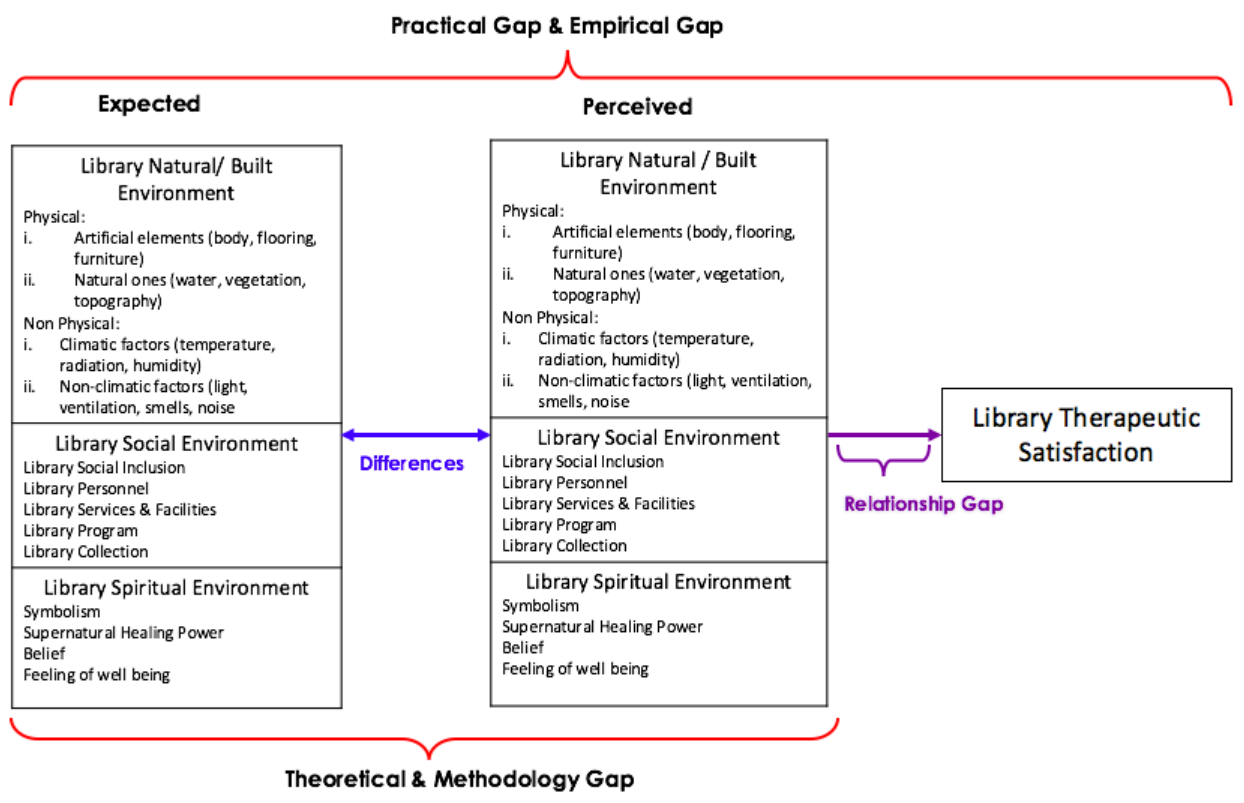

Figure 1. The Conceptual Framework 
INTERNATIONAL JOURNAL OF ACADEMIC RESEARCH IN BUSINESS AND SOCIAL SCIENCES

Vol. 8, No. 9, Sept. 2018, E-ISSN: 2222-6990 @ 2018 HRMARS

This study organized all independent and dependent variables using five-point Likert-type scales to obtain all responses, and using SPSS version 19 to analyze the data. Since it is a newly developed instrument, the Cronbach's alpha scores 6 is allowed. Overall, the data analysis possesses a good reliability standard which indicates that the instrument developed for this study is reliable and suitable.

There is no doubt that this paper presents an overview of ongoing research study. The researcher, who has been in the middle stage of the study, which is to test the realibility of the instrument, can now proceed to the next level of study. This stage is important to ensure that this study does not contain any problem or error in terms of missing data, sample size, non-normality and biasness (Hassan, Schatter and Mazza, 2006) in order to make sure that generalizability of the findings is possible.

As to date, no tool has been produced as a practical instrument which integrates the therapeutic landscape, library service and facilities with acceptable quality and satisfaction. Significantly, it will help organizations in their strategic library planning for good management and development of the society. Public Libraries must improve the quality not only in service but also on the library therapeutic landscapes quality in order to survive and to succeed and have a high quality in performing their services due to the focus of public libraries to serve as an institution that provides a conducive environment to promote well being, and a space for restoration as well as helps to promote holistic healing (Martin et.al., 2005; Wood et.al., 2013; Brewster, 2014; Husaini, Noordin and Shuhidan, 2015). It is hoped that the findings may highlight the insights of the library therapeutic landscape quality conducted by the libraries and the ways they promote high quality and healthy life.

\section{Acknowledgements}

We would like to extend our deepest gratitude to the Ministry of Education of Malaysia, and MARA University of Technology (UiTM), for providing means and opportunities for us to further conduct this research project.

\section{References}

Aarts, $\mathrm{H}$ and Dijksterhuis, AP. (2003). The Silence of the Library: Environment, Situational Norm, and Social Behavior. Journal of Personality and Social Psychology. Vol 4 (1): 18-24

Association of Research Libraries Statistics and Assessment Program. (2014). LibQUAL+ ${ }^{\circledR}$. Retrieved September 12, 2014, from https://www.libqual.org/about/about lq/general info

Brewster, Liz. (2014). The Public Library as Therapeutic Landscape: A Qualitative Case Study. Health \& Place 26: 94-99

Conradson, D. (2005). Landscape, Care And The Relational Self: Therapeutic Encounters In Rural England. Health Place 11 (4). 337. http://Dx.Doi.Org/10.1016/J. Health-Place, 2005.02.004 $-48$

Frederiksen, Lia. (2015). Our Public Library: Social reproduction and urban public space in Toronto. Women's Studies International Forum 48 : 141-153

George, D., \& Mallery, P. (2003). SPSS for Windows step by step: A simple guide and reference. 11.0 update $\left(4^{\text {th }}\right.$ ed.). Boston: Allyn \& Bacon. 
INTERNATIONAL JOURNAL OF ACADEMIC RESEARCH IN BUSINESS AND SOCIAL SCIENCES

Vol. 8, No. 9, Sept. 2018, E-ISSN: 2222-6990 @ 2018 HRMARS

Gesler, W.M. (1993), 'Therapeutic Landscapes: Theory and a Case Study of Epidaurus, Greece', Environment and Planning D 11: 171-89.

Gesler, W.M. (1998), 'Bath's Reputation as a Healing Place', in R.A. Kearns and W.M. Gesler (eds) Putting Health into Place (Syracuse: Syracuse University Press) pp. 17-35.

Glenn Garder, Anne Gardner, Lorna MacLellan, Sonya Osborne. (2003). Reconceptualising the objective of a pilot study for clinical research. International Journal of Nursing Studies. V.4 (7); 719 $-724$.

Hernon, P. \& Nitecki, D. (2001). Service quality: A concept not fully explored. Library Trends 49, 687708.

Husaini H., Noordin, S.A and Shuhidan S.M (2015). Bibliotherapy in the Malaysian Public Libraries: A Conceptual Framework'. The Asian Conference on Literature and Librarianship 2015. Osaka 2 - 5 April. Conference Proceedings; ISSN 2186-2281

Husaini H., Noordin, S.A and Shuhidan S.M (2015). Assessing The Public Library Therapeutic Landscape Quality and Satisfaction: A Conceptual Framework. International Journal of Computer Science and Electronic Engineering. 3 (5): 371 - 374.

Husaini H., Noordin, S.A and Shuhidan S.M (2015). The Public Library as Therapeutic Landscape: Quality and Satisfaction. National Invention Innovation Design Research. Faculty of Information Management, MARA University of Technology, ISBN: 9789834277161

Hassan, Z.A., Schattner, P. and Mazza, D. (2006). Doing pilot study: why is it essential? Malaysian Family Physician, 1 (2\&3), 70-73.

Jiang, Shan. (2014). "Therapeutic Landscapes and Healing Gardens: A Review of Chinese Literature in the Relation to the Studies in Western Countries." Frontiers of Architectural Research 3 (2): 14153.

Kearns, R.A. and Barnett, J.R. (1999) Auckland's Starship Enterprise: Placing Metaphor in a Children's Hospital. Therapeutic Landscapes: The Dynamic Between Place and Wellness. MD: University Press of America, Inc.: 169-99.

Kearns, R.A. and Collins,. (2000) D.C. New Zealand children's health camps: Therapeutic landscapes meet the contract state. Social Science \& Medicine. 5I(7):2000, 1047-59.

Korpela, K.M., Ylen M. (2007). Perceived health is associated with visiting natural favorite places in the vicinity. Health Places 13 (1): 138-151

Krolak Lisa (2005), The role of libraries in the creation of literate environment. A paper prepared for the UNESCO education for all global monitoring report, 2006, literacy for life, Hamburg, Germany, 2006.

Likert, R. (1931). A technique for the measurement of attitudes. Archives of Psychology. New York: Columbia University Press.

Lucas, C. V., \& Soares, L. (2013). Bibliotherapy: A tool to promote children's psychological well-being. Journal of Poetry Therapy, 26(3), 137-147. doi:10.1080/08893675.2013.823310

Malaysian National Library, "The reading profile of Malaysians 2006", (2006) unpublished research

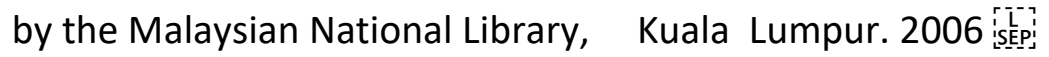

Martin, GP., et.al. (2005) Place, policy and practitioners: on rehabilitation, independence and their therapeutic landscape in the changing geography of care provision to older people in the UK. Soc. Sci. Med. 61 (9): 1983-1904

Motealleh, P. et. al., (2015). Investigating the significance of landscape in designing library by emphasizing on the enhancement of learning. HBRC Journal. http://dx doi:10.1016/j.hbrcj.2014.12.007 
INTERNATIONAL JOURNAL OF ACADEMIC RESEARCH IN BUSINESS AND SOCIAL SCIENCES

Vol. 8, No. 9, Sept. 2018, E-ISSN: 2222-6990 @ 2018 HRMARS

Mohamad Yusoff et. al. (2013). Attitude towards Rural Library Services among Youths in Malaysia. Journal of Basic and Applied Scientific Research. 3(6)777-782.

Noordin S.A, Husaini H. and Shuhidan S.M. (2016). Library Therapeutic Landscape Quality of the Public Library. $27^{\text {th }}$ IBIMA Conference. Milan, Italy: 4 - 5 May

Nunnally, J. C., \& Bernstein, I. H. (1994). Psychometric theory (3 ${ }^{\text {rd }}$ ed.). New York: McGraw-Hill.

Patel Nandish V,. (2003). A Holistic Approach to Learning and Teaching Interaction: Factors in the Development of Critical Learners. The International Journal of education Management 17 (6/7): 272-284

Palka, E. (1999). Accessible Wilderness as a Therapeutic Landscape: Experiencing the Nature of Denali National Park, Alaska. Therapeutic Landscapes: The Dynamic Between Place and Wellness. MD: University Press of America, Inc.: 29-51.

Parasuraman, A. A., Zeithaml, V. A., \& Berry, L. L. (1988). SERVQUAL : A Multiple-Item Scale for Measuring Consumer Perceptions of Service Quality. Journal Of Retailing, 64(1).

SA Noordin, Husaini H. and SM Shuhidan. (2015). Bibliotherapy in Public Libraries: A Conceptual Framework. International Conference on Learning and Technology (ICLT), March 25-26, Singapore Scarpaci, J. (1999). Healing Landscapes: Revolution and Health Care in Post-Socialist Havana. Therapeutic Landscapes: The Dynamic Between Place and Wellness. MD: University Press of America, Inc.: 202-20.

Suhar et. al. (2012). Towards A Better Design: Physical Interior Environment Of Public Libraries In Peninsular Malaysia. Procedia-Social And Behavioral Sciences 42 : 131-143

Thurber, C. and Malinowski, J. (1999). Summer Camp as a Therapeutic Landscape. Therapeutic Landscapes: The Dynamic Between Place and Wellness. MD: University Press of America, Inc.: 53-70.

Tukhareli, Natalia.(2011) Bibliotherapy in a Library Setting: Reach out to Vulnerable Youth. The Canadian Journal of Library and Information Practice and Research, vol. 6, no. 1,2011.

Van Teijlingen, E. R. and Hundley, V. (2001). The importance of pilot studies. Social Research Update Van Teijlingen, E. R., Rennie, A-M., Hundley, V. and Graham, W.(2001). The importance of conducting and reporting pilot studies: the example of the Scottish Births Survey. Journal of Advanced Nursing. 34 (3), (2001), 289 - 295.

Van Teijlingen, E. R. and Hundley, V. (2002). The roles of pilot studies in midwifery research. Retrieved at 2 October 2016; https://www.rcm.org.uk/news-views-and-analysis/analysis/the-role-of-pilotstudies-in-midwifery-research

Williams, A. (2002). Changing geographies of care: employing the concept of therapeutic landscapes as a framework in examining home space. Social Science \& Medicine. 55(1): 141-54

Wilson, K. (2003). Therapeutic Landscapes and First Nations peoples: an exploration of culture, health and place. Health \& Place. 9(2): 83-93.

Winterson, J., 2012. We Must Protect and Reinvent Our Local Libraries. The Guardian, London, 23 November.

Wood, V.J., et al., (2013). Creating "therapeutic landscapes" for mental health careers in inpatient settings: a dynamic perspective on permeability and inclusivity. Soc. Sci. Med. 91, 122-129

Zakaria, Z.; Z.H. Hussin; N. Noordin; M.Z.H.M. Sawal; S.M.A.S. Ahmad Alhady, et al., (2011). Service Quality Dimensions In Public Library: Northern Area Experienced", J. Soc. Sci., 7: 265-270 